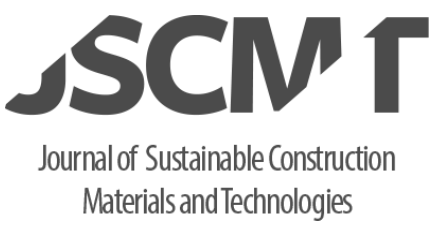

J Sustain. Construct. Mater. Technol. 4(1) (2019) 296-305
Journal of Sustainable Construction Materials and Technologies

www.eds.yildiz.edu.tr/jscmt

\title{
Use of Nanotechnological Building Materials in the Turkish Construction Industry
}

\author{
Yeliz Tülübaş Gökuça,*, Sezgi Turunç ${ }^{\mathrm{b}}$ \\ ${ }^{a}$ Department of Architecture ,Balikesir University, , Balikesir,10145,Turkey \\ ${ }^{\mathrm{b}}$ Architect, Bursa,16110,Turkey
}

Manuscript Received December 4, 2018; Accepted February 4, 2019

\begin{abstract}
The competitiveness of firms in the construction industry can be said to lie on technological developments. Owing to new technologies it is possible to reduce costs and respond to varying customer demands. Nanotechnology affects many sectors as a technology that contributes significantly to the development of the features of materials, and there are many applications in the construction industry as well as in many other areas. Research and development studies have shown that nanotechnology can improve the performance of traditional building materials such as concrete and steel. The construction industry is the major contributor to the environmental problems with the construction, operation and maintenance of buildings. The potential contribution to sustainability is to make the nanotechnology one of the most influential technologies in green buildings. Although nanotechnological materials are ready to be widely used in the construction industry, they have not had an important effect on the sector, yet. The purpose of this study is to better understand the adaptation of nanotechnology in the context of the Turkish Construction Industry, and to evaluate the current applications in nanotechnology. A survey was designed to capture the required data for this study.
\end{abstract}

Keywords: nanotechnology; nanotechnological building material; nanomaterial; construction industry

\section{Introduction}

Nanotechnology has the potential to be the key to a brand new world in the field of construction and building materials [1]. The importance of nanotechnology was emphasized in many research $[2 ; 3 ; 4 ; 5]$. Nonetheless, the demand for nanotechnological materials produced by nanotechnology in the construction industry is limited. The nanotechnology applications mainly depend on the products developed by companies working in the field of chemistry and materials. The importance of nanotechnology in the construction industry has not been clearly defined until recently. Compared to other major industrial sectors, the application of nanotechnology in the construction industry has been left behind due to the lack of awareness of its potential [6]. It is obvious that there is a need for a better understanding of the benefits and effects that may be associated with the use of nanotechnological materials. We will need buildings and building materials that are lighter, more flexible, more durable, longer lasting, less harmful to the environment during the production and the process and be able to utilize renewable energy sources more effectively. It is expected that nanotechnology, one of the most important technology fields of today, will make a significant contribution in the development of building materials with these properties [7].

\footnotetext{
* Corresponding author.

E-mail address: yeliztulubas@ hotmail.com (Y.T. Gökuç)
}

https://doi.org/10.29187/jscmt.2019.33 


\section{Nanotechnology}

The term 'nano' comes from the ancient Greek word 'nanos' meaning 'a dwarf'. The field of nanotechnology was envisioned by Richard Feynman at the annual meeting of the American Physical Society in 1959 at the California Institute of Technology. His famous lecture "There is plenty of room at the bottom" has led the development of nanotechnology. However, the term nanotechnology was first used by Norio Taniguchi in 1974. According to him, nanotechnology is mainly consists of the processing of separation, consolidation, and deformation of materials by one atom or one molecule [8]. Nanotechnology is a rapidly expanding and evolving field, and while this technology was a dream for the past century, today it opens a new horizon for advanced materials. Research in biology, physics, chemistry and engineering conduct the development of nanotechnology and research in this area.

\subsection{Nanotechnology in the Construction Industry}

Nanotechnological materials are shown as one of the most vital materials of the 21 st century. It is possible to see the application areas of nanotechnology in every industry where materials are used. Recent research on nanotechnology materials and nanotechnologies emphasized the potential use of these materials in various fields such as medicine, building, automobile industry, energy, telecommunications and informatics[4]. Construction industry is a sector that holds great economic importance and relevance dealing with coarse components consumed in large amounts, hence with and exceeding requirement for innovations that would work to mitigate such issues [9]. The first nanotechnology applications in constructions began to be used in the mid-90s [5]. A forum was set up to conduct research in order to be able to correctly evaluate the potential and to develop a realistic approach, after the first generation nanotechnological products were launched in the construction markets. These developments followed by the international seminar NICOM1 (International Symposium on Nanotechnology in Construction) held in Scotland, in 2003. In this seminar, a road map titled "The Roadmap for Nanotechnology in Construction" was drawn up for the first time with a vision of 25 years which determined the role of nanotechnology in the construction industry and the research field [5].

Nanotechnology-based products and solutions for the construction industry are in various stages of development, ranging from conceptual ideas to commercially available products[10]. The main nanotechnological materials that can be used in building materials are; Nano-Silica (SiO2), Titanium dioxide (TiO2), Carbon Nanotubes (CNT), Iron Oxide (Fe2O3), Silver Nanoparticles (AgNPs), Copper Nanoparticles (CuNPs), Aluminum Oxide (Al2O3), Magnesium Nanoparticles, Clay, Aerogels. According to Zhu et al. (2004) , the potential applications of nanotechnology in construction may be the following[9]:

Utilization of nanoparticles, nanofibers and carbon nanotubes to improve the quality and stability of building materials, but also to minimize the pollution;

Cheaper manufacture of corrosion-free steel;

Production of thermal insulation materials with very high performance;

Production of ultra-thin layers with the capable of self-cleaning and color-changing in order to reduce pollution and energy use;

Production of nanosensors and nanomaterials with self-repairing ability for more reliable constructions.

Nanotechnological materials, application areas and expected benefits are given in Table 1 below. 
Table 1. Nanotechnological materials, application areas and expected benefits [expanded from Lee et al. (2010)].

\begin{tabular}{|c|c|c|}
\hline Nanotech Materials & $\begin{array}{l}\text { Application } \\
\text { Areas }\end{array}$ & Expected Benefits \\
\hline \multirow[t]{3}{*}{ Nano Silica (SiO2) } & Concrete & $\begin{array}{l}\text { Reinforcement in } \\
\text { mechanical strength }\end{array}$ \\
\hline & Ceramics & $\begin{array}{l}\text { Coolant; light } \\
\text { transmission; fire } \\
\text { resistant }\end{array}$ \\
\hline & Window & $\begin{array}{l}\text { Flame-proofing; } \\
\text { anti-reflection }\end{array}$ \\
\hline \multirow[t]{3}{*}{ Titanium Dioxide (TiO2) } & Cement & $\begin{array}{l}\text { Rapid hydration; } \\
\text { increased degree of } \\
\text { hydration; self- } \\
\text { cleaning }\end{array}$ \\
\hline & Window & $\begin{array}{l}\text { Superhydrophilicity; } \\
\text { anti-fogging; } \\
\text { fouling-resistance }\end{array}$ \\
\hline & Solar cell & $\begin{array}{l}\text { Non-utility } \\
\text { electricity } \\
\text { generation }\end{array}$ \\
\hline \multirow[t]{5}{*}{ Carbon Nanotubes (CNT) } & Concrete & $\begin{array}{l}\text { Mechanical } \\
\text { durability; crack } \\
\text { prevention }\end{array}$ \\
\hline & Ceramics & $\begin{array}{l}\text { Enhanced } \\
\text { mechanical and } \\
\text { thermal properties }\end{array}$ \\
\hline & NEMS/MEMS & $\begin{array}{l}\text { Real-time structural } \\
\text { health monitoring }\end{array}$ \\
\hline & Solar cell & $\begin{array}{l}\text { Effective electron } \\
\text { mediation }\end{array}$ \\
\hline & Nano sensors & $\begin{array}{l}\text { Real time } \\
\text { monitoring of } \\
\text { structures }\end{array}$ \\
\hline Silver Nanoparticles $(A g)$ & Coating/painting & Biocidal activity \\
\hline Copper Nanoparticles $(\mathrm{Cu})$ & Steel & $\begin{array}{l}\text { Weldability; } \\
\text { corrosion resistance; } \\
\text { formability }\end{array}$ \\
\hline Alumina & Concrete & $\begin{array}{l}\text { Improving } \\
\text { mechanical and } \\
\text { physical properties } \\
\text { of concrete }\end{array}$ \\
\hline $\mathrm{Fe} 2 \mathrm{O} 3$ & Concrete & $\begin{array}{l}\text { increased } \\
\text { compressive } \\
\text { strength; abrasion- } \\
\text { resistant }\end{array}$ \\
\hline Clays & Asphalt & $\begin{array}{l}\text { Increasing the } \\
\text { viscosity of asphalt } \\
\text { binders and the } \\
\text { fatigue strength of } \\
\text { asphalt mixtures }\end{array}$ \\
\hline Quantum dots (CdSe) & Solar cell & $\begin{array}{l}\text { Solar Energy } \\
\text { Utlization }\end{array}$ \\
\hline Aerogels & Insulation & $\begin{array}{l}\text { Energy efficiency, } \\
\text { space savings, } \\
\text { moisture } \\
\text { management, design } \\
\text { flexibility }\end{array}$ \\
\hline
\end{tabular}


Although nanotechnology has many benefits, exposure to nanomaterials is becoming one of the most significant risks in the workplace, particularly for the construction industry[11]. The effects of nanotechnological materials on the environment and human health are not clearly defined yet. There are some case studies on environmental exposure that apply construction nanomaterials. Their results indicate that certain levels of exposure are acceptable; for example, analysis of exposure when spraying self-cleaning coatings with nanoparticles of titanium dioxide $\left(\mathrm{TiO}_{2}\right)$ [11]. Another study evaluates exposure when making mortars with nanoparticles of zirconium dioxide $\left(\mathrm{ZrO}_{2}\right)$. It concludes that the occupational limit values were not reached, but they were greater than the values for indoor air[12]. Exposure to materials during manufacturing and use may occur through three mechanisms: Inhalation, dermal contact and ingestion. Minimal information is currently available on dominant exposure routes, potential exposure levels and/or material toxicity[13]. Although current knowledge on the toxicity of nanoparticles and the potential level of worker exposure is very limited, preliminary results in most of the important studies reveal significant biological activity and adverse effects[13].

Table 2. illustrates examples of releasable nanomaterials that may pose hazards on workers' biological systems[14]. Table 2. also shows the possible existence of releasable nanomaterials in construction sites to enhance the quality and performance of construction materials without considering their possible undesirable health effects[15].

Table 2. Examples of different nanomaterials and their toxicological impact on health[14]

\begin{tabular}{|c|c|c|}
\hline Possible Impact on Health & Nanomaterials & Possible Existence in Construction Sites \\
\hline $\begin{array}{l}\text { Damage, leakage, or thinning of the cell } \\
\text { membrane }\end{array}$ & Cationic nanoparticles & $\begin{array}{l}\text { Cement, fasteners, coated surfaces, paint, } \\
\text { flooring, HVAC, and roofing construction } \\
\text { materials }\end{array}$ \\
\hline $\begin{array}{l}\text { Signaling cascade, cytokines, chemokines, } \\
\text { and adhesion inflammations }\end{array}$ & $\begin{array}{l}\text { Cationic nanoparticles and carbon } \\
\text { nanotubes }\end{array}$ & \\
\hline $\begin{array}{l}\text { Mitochondrial damage including e-transfer, } \\
\text { and ATP/PTP opening }\end{array}$ & $\begin{array}{l}\text { Cationic nanoparticles and ultrafine } \\
\text { particles }\end{array}$ & \\
\hline $\begin{array}{l}\text { Protein binding, unfolding responses, } \\
\text { fibrillation, and loss of function }\end{array}$ & $\begin{array}{l}\text { Metal oxide nanoparticles and carbon } \\
\text { nanomaterials }\end{array}$ & \\
\hline $\begin{array}{l}\text { Oxidative stress injury, radical production, } \\
\text { glutathione }(G S H) \text { depletion, lipid } \\
\text { peroxidation, membrane oxidation, and } \\
\text { protein oxidation }\end{array}$ & $\begin{array}{l}\text { Ultrafine particles, carbon nanotubes, metal } \\
\text { oxide nanoparticles, and cationic } \\
\text { nanoparticles }\end{array}$ & \\
\hline $\begin{array}{l}\text { Fibrogenesis and tissue remodeling injury } \\
\text { Blood platelet, vascular endothelial, and } \\
\text { clotting abnormalities }\end{array}$ & $\begin{array}{l}\text { Carbon nanotubes } \\
\text { Silica }(\mathrm{SiO} 2)\end{array}$ & \\
\hline Note: e-transfer $=$ electron transfer $; P T P=$ & neability transition pore & \\
\hline
\end{tabular}

\section{Conducting survey}

The data required for this study, which aims to examine the adaptation of nanotechnological building materials to the Turkish construction industry, were collected by conducting a survey. A preliminary letter and 7questions of a questionnaire were prepared. To scale responses in survey research, 6 the questions are prepared as categorical, and the other question is prepared in likert type. The first two questions of the questionnaire are related to the survey respondents and institutional features of architectural firms. The first question is aimed at determining the institutional age of the firms, and the second question is determining the experience of the respondents in the sector. The thirth question is to measure participants' knowledge levels in nanotechnology. The fourth question is to determine which nanotechnological building materials are used in their firms. Question five of the questionnaire aims to detect the factors that prevent the usage of nanotechnological building materials in the sector. Sixth question is related to investment in nanotechnology. Likert type scaled question was the seventh question in the questionnaire, and it aims whether firms have invested in nanotechnology or not. Participants were asked to indicate their responses on a 5-point likert scale which is rated as; 5- Strongly agree, 4- Somewhat agree, 3- Neither agree nor disagree, 2- Somewhat disagree, 1- Strongly disagree.

This study includes freelance architectural firms, and architects have been identified as survey respondents for this study. The architectural firms in the database of chamber of architects were contacted by e-mail and/or faceto-face negotiations. From 25 different cities a total of 206 firms were contacted, and the questionnaire was evaluated with the data gathered from 190 of them. Due to the lack of information, 16 questionnaires were 
excluded from the evaluation.

\section{Survey results and discussion}

The institutional characteristics of the firms participating in the survey are shown in Figure 1. Figure 1 shows the distribution of the institutional ages, according to this figure $32.11 \%$ of architectural firms have been in operation for 0 to 5 years, $22.63 \%$ for 6 to 10 years, $16.84 \%$ for 11 to 15 years, $10 \%$ for 16 to 20 years and the rest has been operating in the sector for more than 21 years.

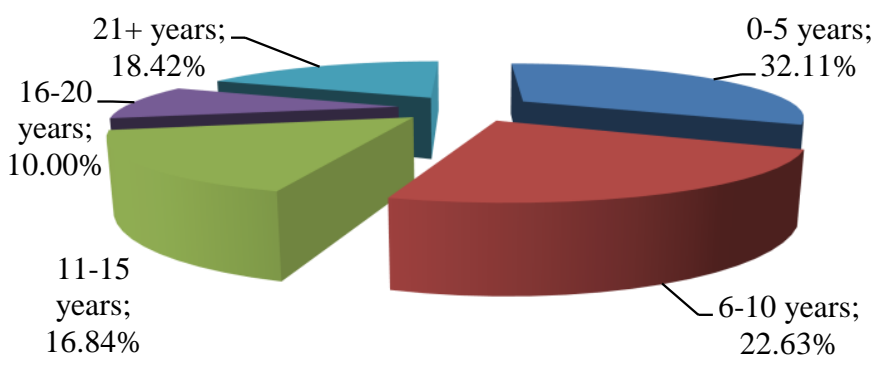

Figure 1. Distribution of firms according to their institutional ages

Figure 2 shows how many years the architects participating in the survey worked in the sector.

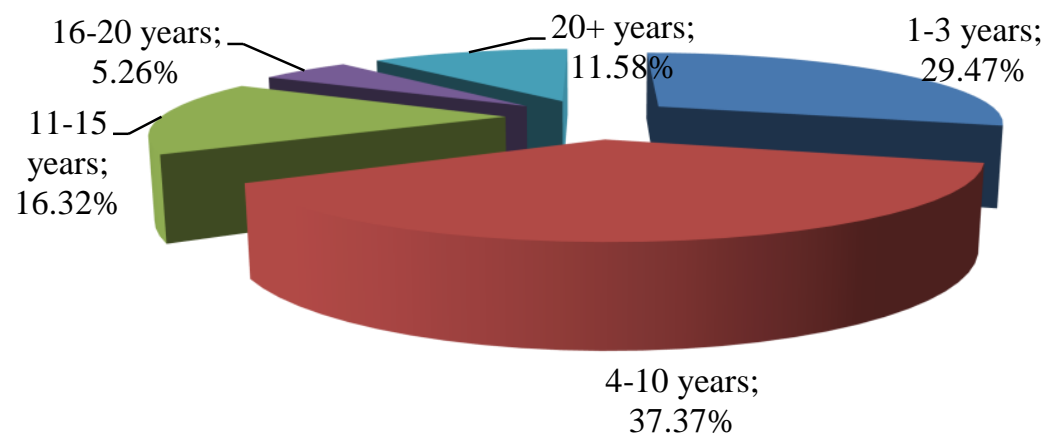

Figure 2. Distribution of survey respondents by years of employment in the sector

$29.47 \%$ of architects have 1 to 3 years of experience, $37.37 \%$ have 4 to 10 years, $16.32 \%$ have 11 to 15 years, $5.26 \%$ have 16 to 20 years. And the remaining $11.58 \%$ have more than 20 years of experience.

Figure 3 shows the participants' knowledge levels on nanotechnological building materials. $8.42 \%$ of respondents have no idea about nanotechnology. $44.74 \%$ of them think that they have some knowledge about the subject, $43.68 \%$ have mid- level knowledge, and 3.16\% of them have a lot of knowledge. And there is no respondents that has very much information about nanotechnological building materials. 


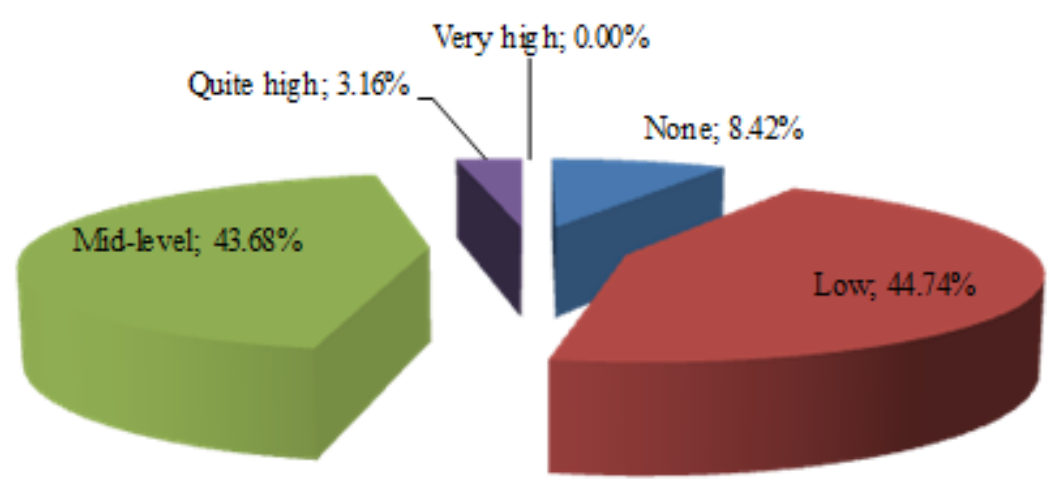

Figure 3. Respondents' knowledge levels in nanotechnology

Figure 4 shows the nanotechnological building materials used by the firms. It is found that approximately $60 \%$ of firms $(58.95 \%)$ do not use nanotechnological building materials at all. On the other hand, the study shows that the first three most used nanotechnological building materials are; (ECT) ceramic nanomaterials $(20.53 \%)$, self-cleaning coatings/paints $(17.37 \%)$ and fire protection nanomaterials $(16.32 \%)$.

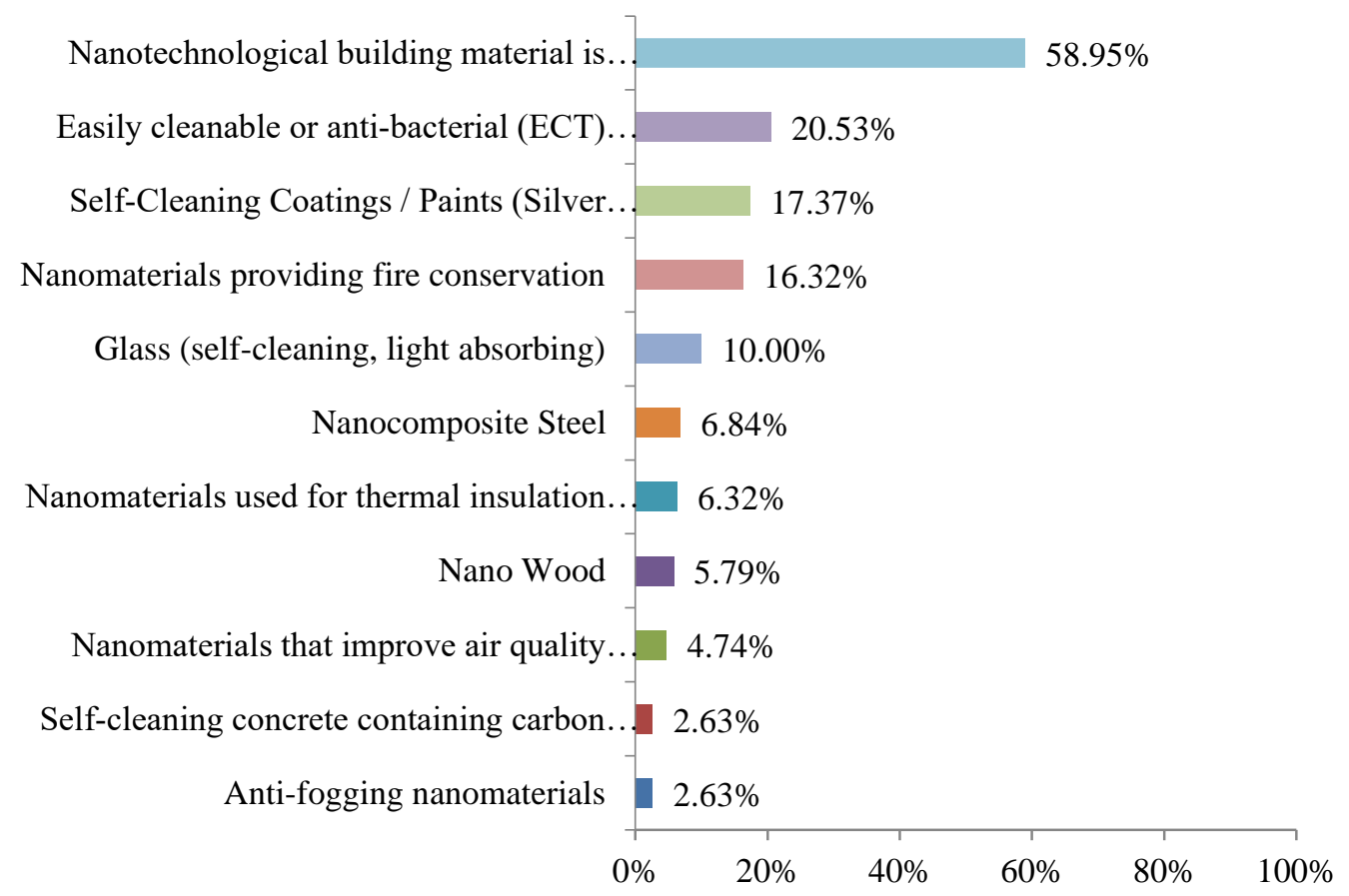

Figure 4. Nanotechnological materials used in the sector

The large number of architectural design firms that have not used nanotechnology (58.95\%) shows that the developments in nanotechnology are not closely watched by architects. Even though, the nanotechnological developments have attracted the academic community by many rational solutions; the increasing usage of nanotechnological new materials and devices can only be realized by understanding the 
relationship between value engineering and technological developments [5]. Figure 5 demonstrates the factors that prevent the architects from using nanotechnological building materials extensively.

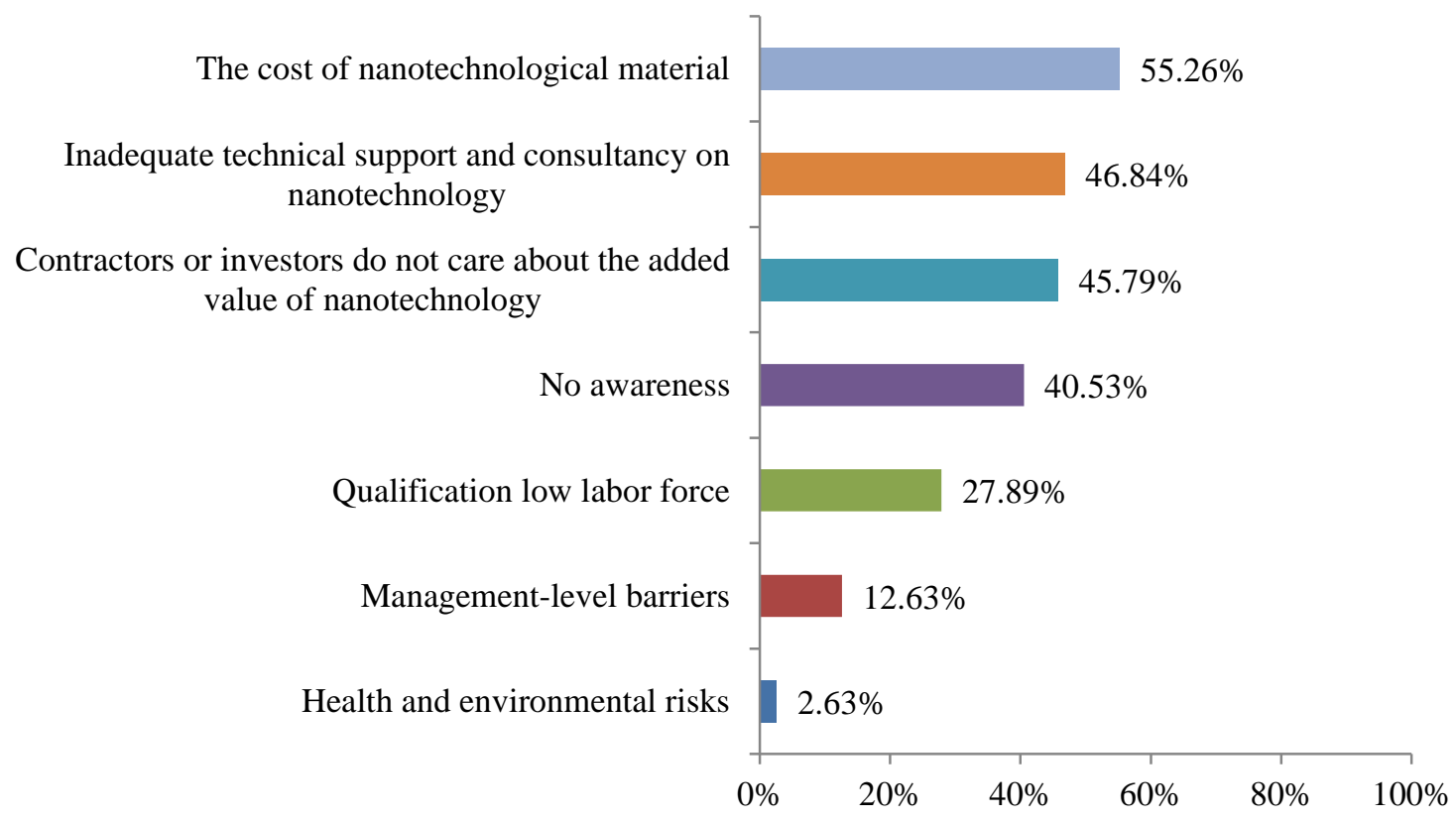

Figure 5. Factors affecting widespread use of nanotechnological materials

Survey shows that; the factors affecting the widespread use of nanotechnological materials are mainly the cost of nanotechnological materials $(55.26 \%)$, the lack of technical support and consultancy in nanotechnology $(46.84 \%)$, and the importance of contractors or investors to the added value of nanotechnological materials $(45.79 \%)$.Several problems and challenges persist and hinder the widespread use of nanomaterial incorporation in the construction industry. These include the absence of mechanical property data, lack of construction experience, and cost of construction[16]. Major construction companies and main contractors are not familiar with nanomaterials, their characteristics and effects. Nanotechnological materials are considerably more expensive than non-nanotechnological alternatives. According to Broekhuizen et al. (2011), high costs are one of the major obstacles to widely acceptance of nanotechnological materials in the sector[17]. Sectoral adaptation of nanotechnological building materials is slow due to the incompatibility between the high cost of nanotechnology products and short-term financial benefits compared to traditional construction materials [18]. According to Scalisi (2017) nanotechnology does represent a relatively recent accomplishment and prices are destined to fall, as is usually the case, over the course of time, with all new technology[19]. Expectations are that costs will decrease over time, as manufacturing technologies improve and demand increases[20]. The low investment in research in the construction industry is another major obstacle to nanotechnology usage. The skepticism of the end-user and the lack of awareness of architects about new materials are other obstacles for the widespread usage of new materials in the construction industry. The use of this technology is not only aimed at improving the properties of conventional materials, but also at monitoring the health and safety of structures and the energy consumptions[18]. According to Hanus and Harris (2013) note that, adoption of nanotechnological products is often hampered by limited product awareness within the industry, the conservatism of the construction industry, and the commonplace focus on up-front build costs over long-term cost, performance, sustainability and safety[10]. Figure 6. shows whether architectural firms are investing in nanotechnology or not. 
Our company makes the necessary investment in nanotechnology.

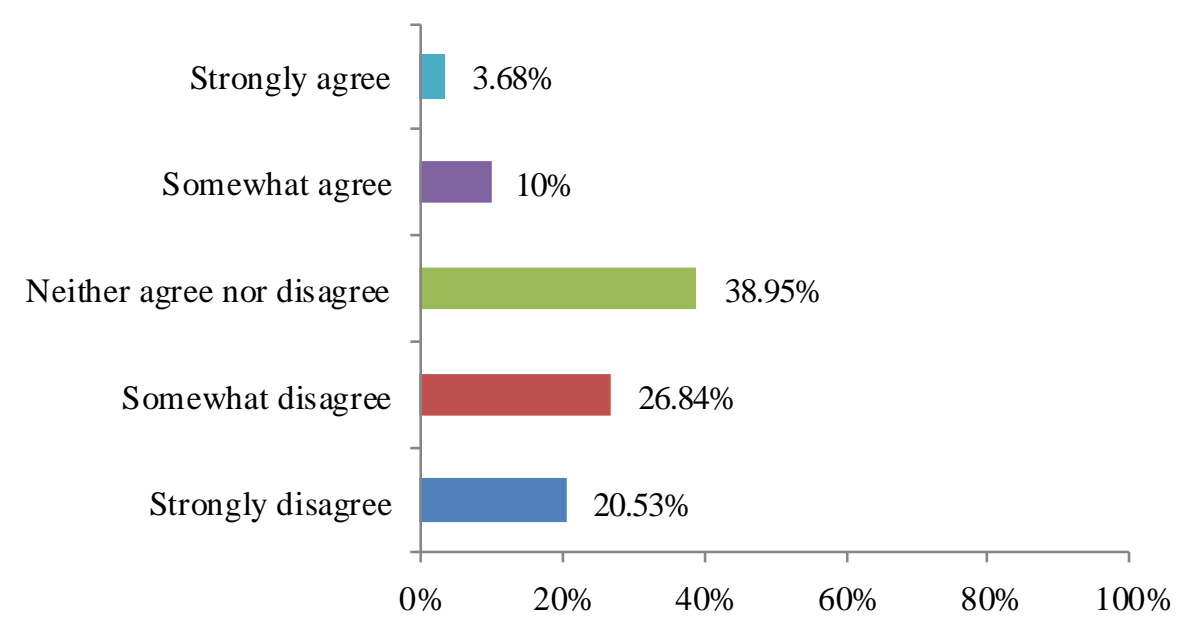

Figure 6. Investment in nanotechnology

Nanotechnology has found application in the construction industry and there are some nano products in the market. However, the use of these products is almost negligible. Today, about $1 \%$ of building-related products have nano-enriched properties. Since the construction sector is not a technology-oriented, it can be concluded that R\&D investments are in very low level. Figure 7. shows whether there are nanotechnology experts or research groups at the firm.

Does your company have an expert / research group working on nanotechnology?

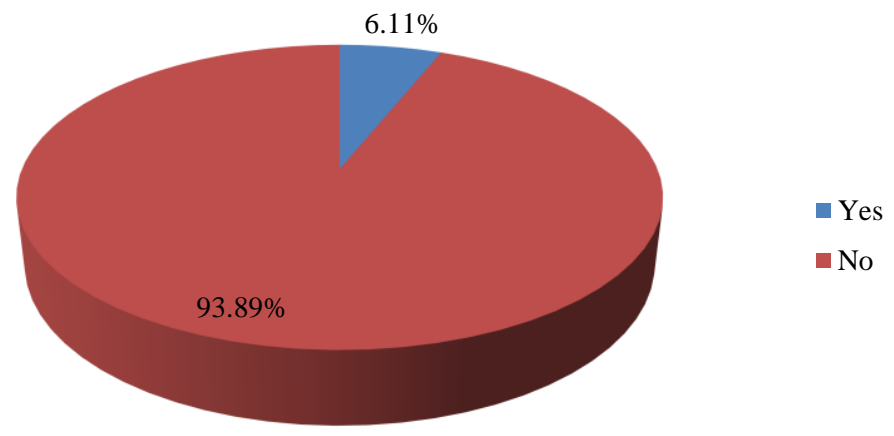

Figure 7. Expert / Research group on nanotechnology existence in participating companies

\section{Conclusions}

Construction industry is a cost-oriented and traditional industry, and not a technology-focused sector. The low investment in research in the construction industry is a major obstacle to nanotechnology. For this reason, the adaptation of nanotechnology applications to the construction industry has been limited. The results of this study reveal that architects are not aware of nanotechnological materials. One of the other important obstacles that affect the widespread use of nanotechnological materials in the industry is the high cost of these materials. Although the cost of nanotechnology material is relatively high, it is expected to decrease over time. The use of nanotechnological materials should be considered not only to enhance material properties and 
functions, but also in the context of energy saving. Less fossil fuel use can be achieved by using high performance thermal insulation materials. Thermal insulation applications reduce the amount of energy used to create comfort conditions and prevent global warming and air pollution. New materials increase the performance of buildings and use of energy is decreasing. The maintenance and repairs become easier since the operating costs are reduced. The various effects of nanotechnological materials on the environment and human health are not clearly defined yet. More studies needed about that.

The construction industry should be considered as one of the strategic sectors where nanotechnology can be applied. Ensuring the university-industry cooperation will increase the possibilities of technology transfer. Nanotechnological materials can increase the competitiveness of companies, since sustainability and energy efficiency become a necessity at present. The number of companies producing and using nanotechnology is very limited in Turkey. Nanotechnology research centers are established in universities. National nanotechnology policies have been identified in the many of EU member countries. Important steps have been taken in nanotechnology area in Turkey, and the construction industry must be supported with incentives. Also, ensuring the sustainability of established research centers is vital.

\section{References}

1. F. Pacheco-Torgal, and S. Jalali, "Nanotechnology: advantages and drawbacks in the field of building materials." Construction and Building Materials, 25 , (2011), 582-590.

2. Z. Ge, and Z. Gao, "Applications of nanotechnology and nanomaterials in construction", First International Conference on Construction In Developing Countries (ICCIDC-I) "Advancing and Integrating Construction Education, Research \& Practice” August 4-5, Karachi, Pakistan, 2008..

3. J Lee, ., S. Mahendra, S Alvarez, P.P.J. "Nanomaterials in the construction industry: a review of their applications and environmental health and safety considerations", ACS NANO, 27,4(7), (2010), 3580-90.

4. R. Olar, "Nanomaterials and Nanotechnology for Civil Engineering." Buletinul Institutului Politehnic Din Iaşi, t. Lvii (Lxi), f. 4, (2011),110-117.

5. J. Bozoglu, ve D. Arditi, "Yapilarda ve yapim yonetiminde nanoteknoloji uygulamalari.” 2. Proje ve Yapim Yonetimi Kongresi, 13 - 16 Eylul (2012), Izmir Yuksek Teknoloji Enstitusu, Urla-Izmir, Turkey. Accessed September 6, 2018.

6. P. J. M. Bartos, "Nanotechnology in construction: a roadmap for development.”, Edited by Z. Bittnar, Bartos P. J. M., Nemecek J., Smilauer, V. and Zeman J., Nanotechnology in Construction: Proceedings of the NICOM3 (3rd International Symposium on Nanotechnology in Construction), Prague, (2009), 15-26.

7. B. Candemir, , B. Beyhan,, S. Karaata, Insaat sektorunde surdurulebilirlik: yesil binalar ve nanoteknoloji stratejileri, IMSAD Yayın No:IMSAD-R/2012-11/374, (2012). Accessed June 10, 2018. Retrived from https://ref.sabanciuniv.edu/sites/ref.sabanciuniv.edu/files/insaat-sektorunde-surdurulebilirlik.pdf

8. N. Taniguchi, Proc. Int. Congress Prod. Eng. Part 2, 18 (JSPE, Tokyo), 1974.

9. W. Zhu,, , P. J. M. Bartos, and, A. Porro. “Application of nanotechnology in construction - summary of a state of the art report, Materials and Structures., 37(273), (2004), 649-658.

10. M. J. Hanus, and A.T. Harris, . "Nanotechnology innovations for the construction industry." Progress in Materials Science, 58, (2013), 1056-1102.

11. B.D. Díaz-Soler, M.D. Martínez-Aires, , and M. López-Alonso. "Emerging risk in the construction industry: Recommendations for managing exposure to nanomaterials”, DYNA, (2016), 83 (196),48-54.

12. S.P.B. Sousa, M.C.S. Ribeiro, and J. Santos-Baptista, , "Potencial risks related to polymer mortars production with nano $\mathrm{ZrO}_{2}$ " Internacional Symposium on Occupational Safety and Hygiene, (2015), 331334. 
13. E. Bakker, "Nanotechnology and human health in the construction industry" (2008), Amsterdam : IVAM BV.

14. H. Meng, T. Xia, S. George, and A. E. Nel. "A predictive toxicological paradigm for the safety assessment of nanomaterials.” ACS Nano, (2009), 3 (7): 1620-1627. https://doi.org/10.1021/nn9005973.

15. A. J. Al-Bayati, and H. A. Al-Zubaidi, "Inventory of Nanomaterials in Construction Products for Safety and Health”, J. Constr. Eng. Manage., (2018), 144(9): 06018004.

16.A. K. Akhnoukh, . "Implementation of nanotechnology in improving the environmental compliance of construction projects in the United States.” Particulate Science and Technology, 36(3), (2018), 357-361.

17. P. V. BroekhuIzen, F. V. BroekhuIzen, R. CornelIssen,, and L. ReIjnders, "Use of nanomaterials in the european construction industry and some occupational health aspects thereof." Journal of Nanoparticle Research 13, (2011), 447-462.

18. A. Sev, and M. Ezel, "Nanotechnology Innovations for the Sustainable Buildings of the Future." International Journal of Architectural and Environmental Engineering, 8(8), (2014), 886-896.

19. F. Scalisi, "Nano-materials for Architecture, Journal of Civil Engineering and Architecture, 11, (2017), 1061-1067.

20. J. Silvestre, N. Silvestre, and, J. de Brito, "Review on concrete nanotechnology." European Journal of Environmental and Civil Engineering, 20 (4), (2016), 455-485. 